\title{
How University Education Student Teachers' Achievement in General Methods of Teaching Course Relates with Their Performance in Teaching Practice
}

\author{
Dr. Patriciah W. Wambugu \\ Faculty of Education and Community Studies, Egerton University, \\ P. O. Box 536-20115, Egerton, Kenya
}

\begin{abstract}
This study investigated the relationship between student teachers' achievement of the general methods of teaching course and their performance teaching practice. It compared the scores in theory and practice. The study was conducted using a random sample of 200 Egerton University 2015/2016 cohort third year education students who had covered the general methods of teaching course and successfully completed their teaching practice. SPSS was used to analyze the data. The scores of the end of semester general methods of teaching examinations and teaching practice were analyzed using Pearson product-moment correlation at $\alpha=0.05$ level of significance. The findings revealed that there was a statistically significant positive relationship between achievement of the general methods of teaching course and performance in teaching practice at $r=0.226$, with $p$ value $=0.004$. The study has implications for teacher training programmes in the refining of teaching practice performance. This means that the general methods of teaching course being a foundational course in student teacher preparation needs critical attention. The teacher educators should enhance the methods of teaching courses with use of current pedagogical strategies to ensure quality training of teachers. In addition, there is need to consider resource allocation for better training. This will help the student teachers to effectively translate theory into practice during teaching practice. This is because teaching practice is an important tool of learning to teach as it promotes development of teaching experience and prepares students for the real world of work. The study recommends that Egerton University should ensure that student teachers are adequately prepared during the methods of teaching courses before engaging in teaching practice sessions and the university to consider increasing the allocation of resources both human and physical. This will ensure teacher effectiveness and quality.
\end{abstract}

Keywords: Student Teacher, Achievement, General Methods of Teaching, Teaching Practice

DOI: $10.7176 / \mathrm{JEP} / 11-5-05$

Publication date: February $29^{\text {th }} 2020$

\section{Introduction}

Teacher preparation is critical since teachers have substantial impact on pupils' life-long success. Further more, teachers are thought to be agents of change in any society as they are key in impacting students. Teachers are the greatest determinant of student achievement and shaping their future which in turn may influence the economic dynamism of a country (Msangya, Mkoma. \& Yihuan, 2016). There is need to have quality teacher training programmes with an effective and efficient mode of delivery and adequate resources. However, research has shown that sometimes student teachers perceive themselves as less prepared when it comes to teaching learners. In addition, globalization presents a challenge to teaching real-world strategies because it is difficult for teachers to keep up with the rapid pace in which knowledge is produced about the world (Rowan, Brownlee \& Ryan, 2019; Myers \& Rivero, 2019). This calls for a thorough and efficient process of equipping the student teachers who can respond effectively to the challenges of the modern world. Hence the need for the general methods of teaching course in the preparation of high school teachers.

In Egerton University, teacher education programmes are such that student teachers are taught foundational courses in the first year of study. The competences of the subject matter are taught throughout the four years of study. In the second year of study the student teachers continue with the development of the subject matter and are also exposed to basic principles of curriculum design and planning. The concepts of curriculum development, purposes, evaluation and dynamics of curriculum change and strategies are also taught in second year of study. Student teachers are expected to be proficient in the third year and are therefore exposed to the general methods of teaching course. They are also taught the subject matter of their specific subjects. The aim of teaching the student teachers the methods of teaching courses is to help them gain skills for classroom teaching. The general methods of teaching course gives student teachers a firm introductory background to the subsequent specific subject methods courses and microteaching. The student teachers are exposed to various aspects of teaching which include; Main approaches to teaching and essentials of good teaching, characteristics and levels of classroom learning. Classroom communication, teaching strategies, effective classroom instruction and methods of evaluation. The student teachers are also introduced to micro-teaching and peer teaching. The exposure of the 
student teachers to these courses is expected to equip them with all the skills, attitudes and knowledge that will help them to effectively teach in high schools. The student teachers then proceed for teaching practice for a period of three months.

Teaching practice is the integral and important aspects in the training and preparation of would be teachers. Teaching practice is the culminating point where the relationship among lecturer, cooperating teacher, and student teacher interface to determine the quality of experience the aspiring teacher will acquire. It also allows student-teachers to apply the theories into practice. The pedagogical competence the student teachers gain during teaching practice is the ability that enhances management of the learning process, such as designing and implementing learning and more importantly their understanding of learners in order to become effective facilitators in developing their learners' potential. The student teachers also gain professional competence which is their' ability in mastering the learning materials in the specific subjects that they teach. This means that they must understand the materials beforehand to deliver the materials widely and deeply to learners. (Genevieve, 2017; Mannathoko, 2013). Further, teaching practice provides student teachers with authentic hands-on experience in teaching which helps them contextualize their theoretical knowledge gained during training. (Mpofu, \& Maphalala, 2018; Owoh \& Udensi, 2017; Ulvik \& Smith, 2011; Kiggundu \& Nayimuli, 2009). Teaching practice plays an important role in pre-service teacher training. If teaching practice is executed rightly and effectively then it will assist in producing high quality professional teachers. Such teachers will be able to play active roles in the development of the teaching process, accommodate rapid educational changes and novel advancements in curricular and instructional activities. Such teachers remain effective and confident and impact on students they interact with (Okendo, 2018; Wambugu, Barmao, \& Ng'eno, 2013). It is therefore imperative that student teachers are exposed to the general methods of teaching before teaching practice.

Teaching practice is a compulsory course in Egerton University for all aspiring student teachers aimed at giving them opportunity to try the art of teaching before getting into the real world of the teaching profession. During this period, the student teachers learn the practical applications of their arts by their own meaningful activities in the classrooms. There are competences that are assessed when the student teacher is on teaching practice. These include preparation of schemes of work which involves writing of the lesson objectives and a clear and appropriately written layout. The student teachers are also assessed in the lesson presentation which includes the introduction, the lesson development and how the lesson conclusion is done. A well-prepared teacher is confident and is able to encourage critical thinking, a strong sense of self-efficacy, and also addresses the needs of the individual student in their classroom experiences (Greathouse, Eisenbach \& Kaywel. 2019). Other areas that are assessed are the mastery of subject matter. The student teacher subject matter may be substantive raging from specific concepts, ideas, topics, knowing how knowledge in the field is generated and validated. This subject matter knowledge is a combination of what the student teachers' experiences in school and the courses taken in the subjects the teacher learnt later in the university. The implication of this reality is that the quality of education experienced by the student teachers as learners during their school and college years has a bearing on the quality of subject matter knowledge, they learnt (Rollnick \& Mavhunga, 2016). This affects their teaching in schools while on teaching practice. That is why the assessment of the mastery of content, relevance and the depth of coverage appropriate to the level the high school learners is important.

The use of teaching and learning resources assists the student teachers in the presentation of the content and achievement of the learning outcomes. At the same time it helps the teacher explain difficult concepts and make learning interesting hence motivating the learners. In addition, learning proceeds from the known to the unknown. This inductive method of learning where reasoning progresses from specific to general constitutes effective learning. A rich lesson requires creativity and integration of resources for proper understanding of concepts by the learners (Wambugu \& Wachanga 2019; Ong'amo, Ondigi \& Omariba, 2017). This makes it necessary to assess student teachers utilization of teaching and learning resources in terms of relevance, creativity, timeliness of use while teaching and even the proper use of readily available materials. The student teachers are assessed on class organization and management, the teacher personality and assessment and evaluation of the learners. It is therefore critical that the student teachers are well prepared and exposed to these competences before proceeding for teaching practice. Thorough preparation of the student teachers is required to enable the student teachers to effectively demonstrate their understanding and application of the competences (Lucenario, Yangco, Punzalan \& Espinosa, 2016).

The third year of the teacher education programme incorporates the key tenets of integrated theory and practice, and prepare the student teachers for realities of the teaching profession by effectively contextualizing their learning with practice. Teacher preparation is critical because it removes disparity between the student teachers' classroom realities and the teaching experiences in schools (Green, Eady. \& Andersen, 2018; Genvieve, 2017). The teacher education programme in Egerton University aims at implementing the key tenets of the general methods and the specific subject methods to prepare quality graduate teachers. The general methods of teaching course prepare students to be effective teachers, who can help high school students to learn as measured by the value added in positive academic, attitudinal and social outcomes. The preparation of effective teachers 
requires the student teachers to have school practice skills that are designed to create and strengthen strong relationships between student and teachers in both academic and social-emotional settings. This therefore makes the general methods of teachings course critical in teacher preparation. The course helps student teachers to master competences in and across various domains of teaching and learning which include; nature and components of teaching and learning process, classroom communication, organization and management of teaching and learning, systems approach to instructional process, instructional strategies and planning and instruction. The student teachers are also exposed to microteaching and peer teaching. This kind of training requires adequate human and physical resources. However, reduced funding in the University education and inadequate teaching resources, fewer academic staff and technicians who assist in preparing student teachers for teaching practice may negatively affect the situation. In addition, the 21 st century, knowledge and new technologies are growing exponentially. This calls for education that will provide learning experiences focused on deep learning that will enable learners think critically and solve problems. This situation demands for teachers who can meet the needs of today's learners. This may require teacher preparation that will ensure that the student teachers have the necessary pedagogical skills to enable them handle the demands. However, it is not clear whether the current teaching through the general methods course prepares student teachers to adequately handle their teaching and learning process in a professional way and especially during their teaching practice.

\section{Objective of the Study}

The objective of this study is to establish whether there is a relationship between the student teachers' achievement in general methods of teaching course and their performance in teaching practice.

\section{The hypothesis of the study}

Ho1 There is no statistically significant relationship between the student teachers' achievement in the general methods of teaching course and their performance in teaching practice

\section{Conceptual Frame work}

This study is framed through the two conceptual lenses about methods of teaching and the influence on student teacher teaching experience.

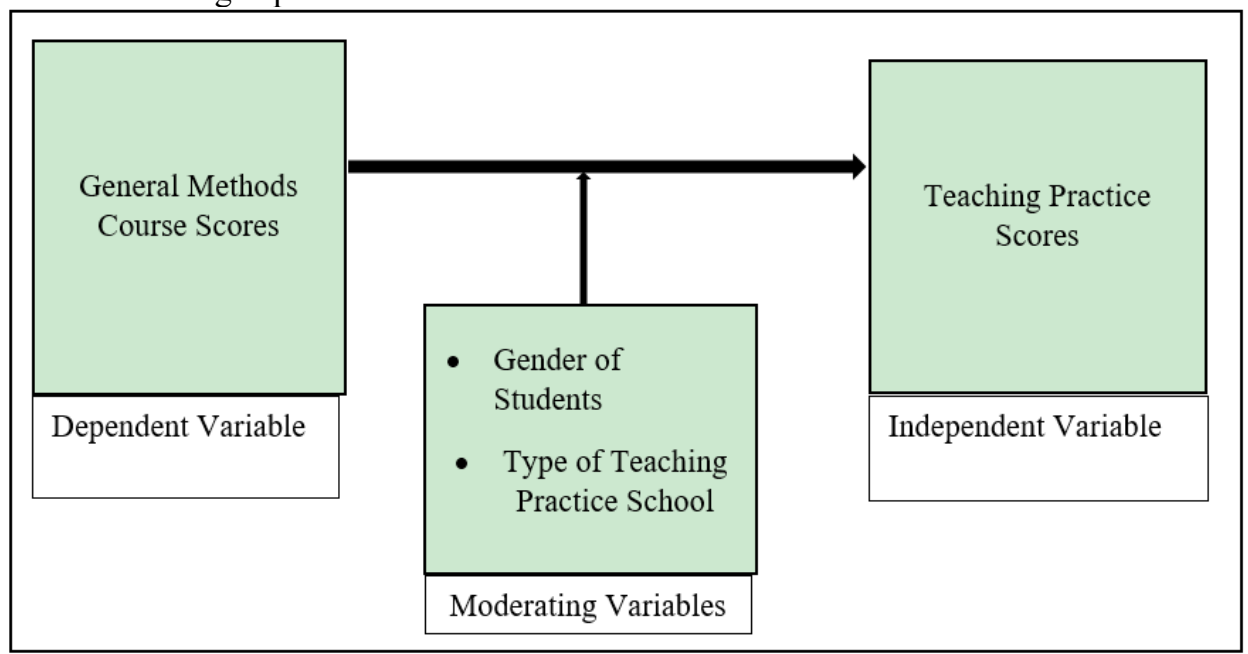

Figure 1. Conceptual Framework of the Study Showing how Variables of the Study are Related

The general methods course score is the independent variable that may affect the teaching practice performance. Moderating variables are likely to affect the directions of strength of the relationships between the general methods of teaching course and the performance in teaching practice. The students are subjected to the same training experiences and assessment of the course. Thus, the training is expected to produce student teachers with effective teaching skills, good personal and affective characteristics irrespective of gender. This is in agreement with (Ahiatrogah, 2017), who examined gender dimension in the development of effective teaching skills among distance education (DE) students and found out that there was no statistically significant difference between the teaching skills acquired by male and female students during On-Centre-Teaching-Practice. Further, teaching practice schools are chosen so that every school has sufficient resources and learning environment to enable teachers carry out their practicum.

\section{Methodology}

The Correlational Research Design was used in the study. A random sample of 200 third year students was obtained from the 2015/2016 cohort who had covered the general methods of teaching course and successfully 
completed their teaching practice.

Document analysis of scores for the general methods of teaching course for the sampled student teachers were used. The scores of the methods course were obtained from their Continuous Assessment and end of semester examinations. These examinations cover the various aspects of teaching and learning, are moderated by experienced university lecturers and therefore deemed to be reliable. The scores teaching practice were obtained through the teaching Practice Observation Instrument (TPOI). The instrument covered the following areas; Planning for teaching, presentation, use of resources, student teacher personality, classroom management and learning evaluation. This instrument was validated by experts from the Faculty of Education and Community Studies of Egerton University. The student teachers were scored by experienced Faculty of Education and Community Studies lecturers who observed the actual teaching in the schools. The scored data was cleaned to remove the outliers then analyzed using SPSS to calculate the means scores, distribution of the scores and the Pearson correlation coefficient.

\section{Results and Discussion}

The general methods course work is very important in the preparation of student teachers because this is when they are taught on the planning to teach, how to carry out the actual teaching, classroom management and evaluation of learning. This theory is put in practice during the real teaching experience in schools. The interaction between the lecturer and the student teachers is critical in this preparation. It is therefore important to find out whether there is any relationship between the acquisitions of teaching skills by student teachers from the general methods of teaching course and what they practically do in the classrooms during teaching practice. The Pearson's Correlation with means and standard deviations was run in SPSS to determine the relationship between the general methods of teaching course scores and the teaching practice performance as shown in Table 1 and Table 2 . The study sought to find out whether there was a statistically significant relationship between the general method of teaching course mean score and the teaching practice performance as stated in Ho1.

Table 1. The Means Scores and Standard Deviation for the General Methods of Teaching Course and Teaching Practice Scores

\begin{tabular}{|l|l|l|l|l|}
\hline & N & Mean & Std. Deviation & Std. Error Mean \\
\hline General Methods of Teaching scores & 159 & 61.6981 & 7.47549 & .59285 \\
Teaching Practice Scores & 159 & 70.4151 & 6.32185 & .50136 \\
\hline
\end{tabular}

Table 1 shows that the mean scores achievement in the general methods course was lower than that of teaching practice. This may be attributed to the fact that the student teachers are able to put in practice the skills gained from the exposure of the general methods of teaching course. It was therefore necessary to carry out a statistical test to find out whether there is any relationship between the general methods of teaching scores and the teaching practice performance. This was done by drawing scatter plot (Figure 1) and the Pearson's Correlation coefficient shown in Table 2.

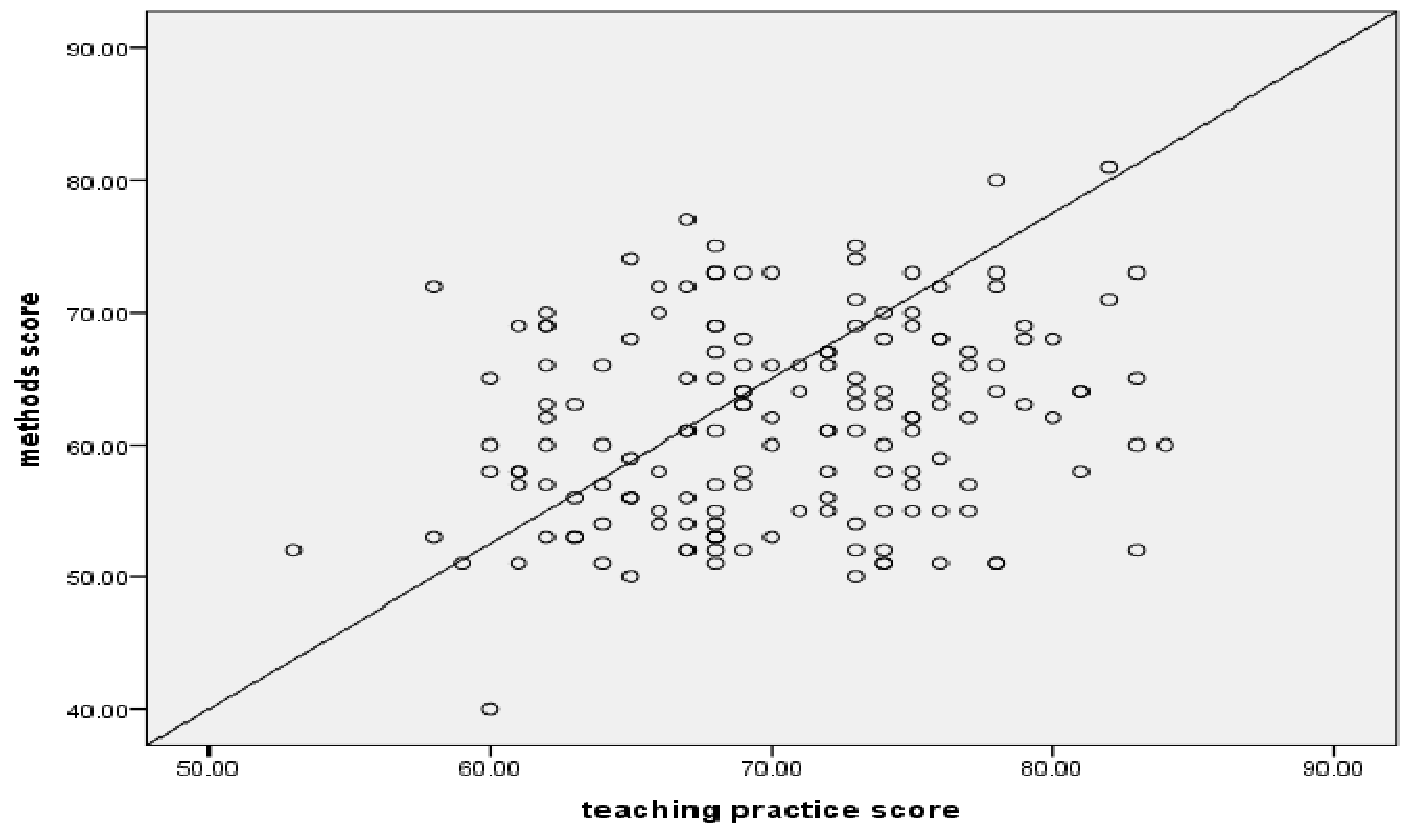

Figure 1: Scatter plots for the methods course and teaching practice scores

The scatter plot in Figure 1 shows a positive correlation between the methods scores and the teaching 
practice performance. This means that a student who did well in the general methods course could also perform better in the teaching practice.

Table 2. Pearson Correlation between the General Methods and Teaching Practice Mean Scores

\begin{tabular}{|c|c|c|c|}
\hline & & Methods mean scores & $\begin{array}{l}\text { Teaching Practice mean } \\
\text { scores }\end{array}$ \\
\hline Methods mean Scores & $\begin{array}{l}\text { Pearson Correlation } \\
\text { Sig. (2-tailed) } \\
\text { N }\end{array}$ & $\begin{array}{l}1 \\
159\end{array}$ & $\begin{array}{l}.226^{* *} \\
.004 \\
159\end{array}$ \\
\hline $\begin{array}{l}\text { Teaching Practice mean } \\
\text { Scores }\end{array}$ & $\begin{array}{l}\text { Pearson Correlation } \\
\text { Sig. (2-tailed) } \\
\text { N }\end{array}$ & $\begin{array}{l}.226^{* *} \\
.004 \\
159\end{array}$ & $\begin{array}{l}1 \\
159\end{array}$ \\
\hline
\end{tabular}

**. Correlation is significant at the 0.01 level (2-tailed)

It can be observed from Table 2 that $r=0.226$, with $\mathrm{p}$ value $=0.004$ which is less than 0.05 . This indicates that there is a significant positive relationship between the preparation of the student teachers in the general methods of teaching course and the actual performance in teaching practice in schools. This means therefore that hypothesis one is rejected. This is an indicator that the student teachers were able to put in practice skills acquired during preparation of the in the methods course. In the methods course which is a pre-requisite for teaching practice the student teachers taught in details all aspects of learner behavior, the planning of lessons and presentations, the evaluation of the learning process and the entire classroom management. The improved performance in teaching practice shows that the student teachers are able to put theory learnt into practice which is an implication of good teaching. Oloo (2011) alludes that one of the abilities of good teaching is planning and taking care of individual differences in the classroom. This is expressed in the valued added in the teaching practice performance of the student teachers.

The student teachers are trained in the general methods of teaching course on how to plan and execute lessons using a variety of teaching strategies and appropriate use of learning resources to enrich and clarify the curriculum content. They are also taught the effective use of psychological theories of learning in the classroom and continuous motivation of learners. The Positive significant relationship between the general methods of teaching course and teaching practice shows that the student teachers are able to put in practices the theory in a real classroom situation. It can also be observed that $r=0.226$ is a positive relationship, indicating that the general methods of teaching course affects the performance of the student teacher in the practicum. This positive correlation between the general methods of teaching and the teaching practice scores, means that the student teachers acquire knowledge, skills and attitudes in teaching that they are able to apply during practicum. The general methods of teaching course being a foundational course to student teacher preparation and needs critical attention. The teacher educator student interactions need to be increased and should also be enhanced with use current pedagogical skills and more teaching and learning resources. This will help the student teachers translate theory into practice during the teaching practice as alluded by Kiggundu \& Nayimuli (2009). Further, Oluwafemi (2010) asserts that teachers who have gone through the methods course are able to orient to the teaching practice situations without difficulties. The training of general methods of teaching course may significantly improve student teacher performance in teaching practice. Therefore, general methods of teaching course being a foundational course to student teacher preparation needs critical attention. The teacher educator student interactions need to be increased and should also be enhanced with use of current pedagogical skills and more teaching and learning resources.

\section{Conclusion}

This study established that the students who achieve high scores in the general methods of teaching course are superior in teaching practice performance. Since the general methods of teaching course trains student teachers on gaining knowledge and skills and to have proper attitudes towards teaching, it is clear that the student teachers are able to translate this into a teaching practice experience. Therefore, the general methods of teaching course should be supported and enhanced with the necessary training physical and human resources in the teacher education institutions. The study also established that the general methods of teaching score is not a predictor of the teaching practice score. This could be as a result of the student teachers being exposed to the methods of teaching specific subjects and micro teaching before proceeding for practicum.

\section{References}

Ahiatrogah P. D. (2017). Gender Dimension in the Development of Effective Teaching Skills Among University of Cape Coast (Ucc) Distance Education Students. World Journal of Education. http://wje.sciedupress.com 7 (4) $12-23$.

Darling-Hammond L., Flook L., Cook-Harvey C., Barron B. \& Osher D. (2018). Implications for Educational 
Practice of the Science of Learning and Development. Applied Developmental Science. https://doi.org/10.1080/10888691.2018.1537791. 1-44

Genevieve A. (2017). The Role of Teaching Practice in Teacher Education Programmes: Designing Framework for Best Practice. Global Journal of Educational Research 16, 101-110

Genvieve N. (2017). Preparation of Teacher-Trainees in Pedagogy in Kenyan Universities. Journal of Education and Practice 8 (13), 28-34

Greathouse P. Eisenbach B.B. \& Kaywel J. F (2019). Preparing Teacher Candidates to be "Effective" in the Classroom: Lessons Learned from National Teachers of the Year. A Journal of Educational Strategies, Issues and Ideas 92 (1-2) 39-47

Green, C., Eady. M., \& Andersen, P. (2018). Preparing quality teachers. Teaching \& Learning Inquiry, 6(1). http://dx.doi.org/10.20343/teachlearninqu.6.1.10

Lucenario J. L. S., Yangco R. T., Punzalan A. E., \& Espinosa A. (2016). Pedagogical Content KnowledgeGuided Lesson Study: Effects onTeacher Competence and Students' Achievement in Chemistry. Education Research Internationa.l 1-10

Kiggundu E. \& Nayimuli S. (2009). Teaching practice: a make or break phase for student teachers. South African Journal of Education, (29) 345-358

Mannathoko M. C. (2013). Does Teaching Practice Effectively Prepare Student-Teachers to Teach Creative and Performing Arts? The Case of Botswana. International Journal of Higher Education. http://dx.doi.org/10.5430/ijhe.v2n2p115 2(2) 115-121

Mpofu, N. \& Maphalala, M.C. (2018). A comprehensive model for assessing student teachers' professional competence through an integrated curriculum approach', The Journal for Transdisciplinary Research in Southern Africa https://doi.org/10.4102/td.vl4i.48614(2)

Msangya B. W., Mkoma S. L. \& Yihuan W.(2016). Teaching Practice Experience for Undergraduate Student Teachers: A Case Study of the Department of Education at Sokoine University of Agriculture, Tanzania. Journal of Education and Practice. www.iiste.org 7(14) 113-118

Myers J. P.\& Rivero K. (2019). Preparing Globally Competent Preservice Teachers: The Development of Content Knowledge, Disciplinary Skills, and Instructional Design. Teaching and Teacher Education (77) 214-225

Okendo, O. E. (2018). Student Teachers' Perceptions of Teaching Practice Assessment of Mwenge Catholic University, Tanzania. Journal of Education and Practice www.iiste.org ISSN 2222-1735 (Paper) ISSN 2222-288X (Online) 9(11) 99-105

Oloo, E. O. (2011). Factors Influencing Performance of student teachers on teaching Practice of selected Primary teachers' Colleges in Western Province Kenya. Unpublished thesis, University of Nairobi

Oluwafemi, B. (2010). Effects of Teaching Practice on Student Teachers Tertiary Institutions in Nigeria. Kogi State Polytechnic https://www.grin.com/document/182582

Ong'amo B. L., Ondigi S. R., \& Omariba. A. (2017). Effect of Utilization of Biology Teaching and Learning Resources on Students' Academic Performance in Secondary Schools in Siaya District - Kenya. International Journal of Education and Research (5) 1 253-272.

Owoh T. M. \& Udensi, E, O. (2017). Student Teachers' Perceptions about Teaching Practice Evaluations by Supervisors and Co-Operating Teachers in Enugu State. International Journal in Management and Social Science, (5)11, 250-260 ISSN: 2321-1784

Rollnick, M. \& Mavhunga, E. (2016). The Place of Subject Matter Knowledge in Teacher Education IN John Loughran and MaryLynn Hamilton (Eds). The International Handbook on Teacher education Dordrecht: Springer, 423-452.

Rowan L., Brownlee J. L. \& Ryan M. (2019). Teaching teachers: what [should] teacher educators "know" and "do" and how and why it matters, Asia-Pacific Journal of Teacher Education, 47:3, 210-215, DOI: 10.1080/1359866X.2019.1601837

Ulvik M. \& Smith K. (2011). What Characterizes a Good Practicum in Teacher Education? Education Inquiry 2 , (3),.517-536

Wambugu P., Barmao, A.\& Ng'eno J. (2013). Student Teachers' Perceptions of Teaching Practice Assessment in Egerton University, Kenya. Education Journal. (2)4 169-175. doi: 10.11648/j.edu.20130204.20

Wambugu P. W. \& Wachanga S. W (2019). Influence of Student Teachers' Gender, Personality and Programme of Study on their Use of Learning Resources during Teaching. Case of Egerton University. African Journal of Educational and Social Science Research 7 (3), 2617-7315 